Ecohydrology

\title{
Diatom sensitivity to hydrological and nutrient variability in a subtropical, flood-pulse wetland
}

\begin{tabular}{|r|l|}
\hline Journal: & Ecohydrology \\
\hline Manuscript ID: & ECO-10-0159.R1 \\
\hline Wiley - Manuscript type: & Research Article \\
\hline Date Submitted by the & $\mathrm{n} / \mathrm{a}$ \\
\hline Complete List of Authors: & $\begin{array}{l}\text { Mackay, Anson; UCL, Geography } \\
\text { Davidson, Thomas; UCL, Geography } \\
\text { Wolski, Piotr; University of Botswana, Okavango Research Institute } \\
\text { Woodward, Selina; UCL, Geography } \\
\text { Mazebedi, Richard; University of Botswana, Okavango Research } \\
\text { Institute } \\
\text { Masamba, Wellington; University of Botswana, Okavango Research } \\
\text { Institute } \\
\text { Todd, Martin; University of Sussex, Geography }\end{array}$ \\
\hline Keywords: & $\begin{array}{l}\text { diatoms, wetlands, water level regime, Okavango Delta, } \\
\text { biodiversity, multivariate techniques }\end{array}$ \\
\hline
\end{tabular}

\section{SCHOLARONE ${ }^{\text {m }}$ \\ Manuscripts}


1 Diatom sensitivity to hydrological and nutrient variability in a subtropical, flood-

2 pulse wetland

3

4 Short title:

5 Diatoms of the Okavango Delta

6

7 Anson W. Mackay ${ }^{1}$

8 Thomas Davidson ${ }^{1,2}$

9 Piotr Wolski ${ }^{3}$

10 Selina Woodward ${ }^{1}$

11 Richard Mazebedi ${ }^{3}$

12 Wellington R.L. Masamba ${ }^{3}$

13 Martin Todd $^{1,4}$

14

151 ECRC, Department of Geography, UCL, Gower Street, London WC1E 6BT

162 Institute of Bioscience, NERI, Aarhus University, Vejlsøvej 25, DK-8600

17 Silkeborg, Denmark

183 Okavango Research Institute, University of Botswana, Private Bag 285, Maun,

19 Botswana

204 Department of Geography, University of Sussex, Brighton, BN1 9RH UK

21

22 Corresponding author:

23 Anson W. Mackay

24 Department of Geography, UCL

25 Gower Street, London. WC1E 6BT

26 a.mackay@ucl.ac.uk

27 p: 0207679 0558; f: 02076790565 


\section{ABSTRACT}

30 The principal aim of this study was to disentangle hydrochemical influences on

31 primary producers in a pristine, flood-pulse ecosystem. This was undertaken by

32 analyzing diatoms from 100 sample points from hydrologically distinct regions in the

33 Okavango Delta, Botswana. Cluster analysis was undertaken using two-way indicator

34 species analysis (TWINSPAN), and groups used to classify sample points in a

35 principal components analysis (PCA) biplot. Linear discriminant analysis (LDA) was

36 performed using hydrological data and diatom guilds as explanatory variables. A

37 series of ordinations using redundancy analysis (RDA) was undertaken to assess

38 which variables significantly accounted for diatom variation across the Delta. Species

39 response curves for major taxa were generated using generalized additive models

40 (GAMs). Cluster analysis revealed six distinct groups. Groups 5 and 6 consisted

41 mainly of seasonally inundated floodplain sites, which lay at one end of a significant

42 gradient revealed by PCA. Floodplain diatoms were characteristically N-heterotrophs,

43 requiring elevated concentrations of key resources such as total nitrogen (TN) and

$44 \quad \mathrm{SiO}_{2}$. Using forward selection, constrained $\mathrm{RDA}$ reveals five variables were

45 significant in explaining diatom distributions across the Delta: hydroperiod class,

46 flood frequency, flow velocity, and nutrients $\mathrm{SiO}_{2}$ and TN. Species response curves

47 show that motile diatoms were most abundant in seasonally inundated floodplains.

48 Species diversity was significantly higher in the upper Panhandle region of the Delta,

49 which may be related to moderate levels of disturbance and increased resource

50 limitation. Species diversity was significantly lower during the period of maximum

51 flood extent, which may in turn be related to fewer limiting resources.

52

53 Keywords

54 Diatoms, biodiversity, wetlands, multivariate techniques, water level regime, diversity

55 indices, Okavango Delta, Botswana

56

57 


\section{Introduction}

60

61 Tropical and subtropical wetlands are of profound importance for humankind,

62 providing vital ecosystem services through the provision of freshwater, food and

63 biodiversity (Millennium Ecosystem Assessment, 2005). Many of these wetlands

64 experience periodic, regular flooding (flood-pulse concept; Junk et al., 1989), which

65 in turn controls nutrient recycling and biological growth in floodplain habitats. Where

66 flood pulses are regular, organisms develop adaptations to exploit periodic wetting;

67 hydrological regimes have been shown to be a major influence on primary

68 productivity and on the composition of primary producers, especially diatom

69 microalgae (Class Bacillariophyceae) (e.g. Gell et al., 2002; Weilhoefer et al., 2008).

70 Microalgae cause changes in water chemistry (e.g. $\mathrm{pH}$ ) through photosynthesis and

71 respiration. For example, diurnal fluctuations in oxygen concentrations can affect

72 temporal and spatial distributions of invertebrates and fish (Suthers and Gee, 1986).

73 Microalgae also contribute to nutrient cycling and wetland biogeochemistry. Diatoms

74 in particular are very important because they have siliceous frustules which contribute

75 to both carbon and silicon regulation (Struyf and Conley, 2009). Diatoms are also

76 extensively used to monitor wetland ecosystems and human impact (Lane and Brown,

77 2007) including nutrient enrichment (e.g. McCormick and Stevenson, 1998) and

78 salinisation (e.g. Tibby et al., 2007). However, in regions that experience strong

79 hydrological variability, bioassessments using biological proxies such as diatoms are

80 prone to significant uncertainty associated with the changing flood pulse (Wilcox et

81 al., 2002; Weilhoefer et al., 2008).

82

83 In Africa, water availability is distributed very unevenly, and in semi-arid regions

84 availability is especially sensitive to rainfall. Wetland degradation in Africa is highly

85 significant; for example in recent decades over $80 \%$ of freshwater wetlands in Niger

86 have disappeared (UNEP, 2000). However, across the continent as a whole, scientific

87 research on wetlands has been rather inconsistent, such that estimates of area covered

88 range between 220,000 and 1,250,000 $\mathrm{km}^{2}$ (Bullock et al. in Schuyt 2005). The

89 Okavango Delta (hereafter referred to as the Delta) is one of Africa's few remaining

90 pristine wetlands, and therefore modelling impacts of changing hydrology on primary

91 producers can be undertaken with minimal influence from anthropogenic stressors. 
92 The Delta is part of the Okavango River Basin (ORB), which straddles Angola,

93 Namibia and Botswana (Fig 1). It lies in the lowest region of the Kalahari Basin, and

94 its resources are fundamental to the health and livelihood of hundreds of thousands

95 people, the majority of whom live below the poverty line (Kgathi et al., 2006). Angola

96 has only recently emerged from decades of civil war, and economic development is

97 relatively weak. However, there is great potential for water to be used for irrigation

98 and hydropower generation (Pinheiro et al., 2003). In northeast Namibia, the

99 Okavango River transverses through the semi-arid, highly populated Kavango region,

100 a major centre of food production that is strongly reliant on the Okavango River for

101 irrigation water (Kgathi et al., 2006). There have been several plans to build hydro-

102 electric dams in Namibia, although these have yet to be realised (Mendelsohn et al.,

103 2010). In Botswana, the Delta is a major source of income through tourism, but

104 because the majority of water enters from neighbouring countries, the Delta is

105 potentially at risk from upstream activities and economic development (Ashton,

106 2002). For example, modelling studies have suggested that water abstraction and dam

107 building may lead to an increase in dryland regions (Murray-Hudson et al., 2006),

108 while deforestation of the riparian zones may lead to an increase in permanently

109 flooded regions (Andersson et al., 2006).

110

111 The Delta is a flood-pulse ecosystem and receives water mainly from the Okavango

112 River (c. $9 \times 10^{9} \mathrm{~m}^{3} \mathrm{yr}^{-1}$ ) and from local summer rainfall (c. $6 \times 10^{9} \mathrm{~m}^{3} \mathrm{yr}^{-1}$ ) (McCarthy

113 et al., 2003). The Delta consists of a complex mosaic of wetland and dryland habitats

114 (linked by its variable, annual flood regime), and is a Ramsar Wetland of International

115 Importance. The Delta supports very high levels of local biological productivity and

116 mammalian biomass (estimated to reach $12 \mathrm{t} \mathrm{km}^{-2}$; Junk et al., 2006), because its

117 spatial extent is greatest during winter when rainfall is at its lowest. The Delta is

118 therefore a significant biodiversity reservoir, representing the southernmost limit of

119 many Zambezian species, and the largest breeding populations of various Red Data

120 species globally (Ramberg et al., 2006).

122 Seasonal inundated floodplains are of profound importance in the Delta; they link

123 terrestrial and aquatic habitats, and are the regions where nutrients are mobilized on

124 wetting, resulting in new cycles of biological production (Mendelsohn et al., 2010).

125 Only limited work in the Delta has been done investigating primary producers, and 
126 microalgae research, especially diatoms, has been particularly neglected. Many fish 127 species spawn in the Delta floodplains, but the interactions between microalgae, fish 128 and protected consumers (e.g. the Wattled crane) are poorly understood. Previously, 129 Cholnoky (1966) undertook a qualitative investigation of diatoms in the ORB, 130 although only a few sites were from the Okavango Delta and neighbouring regions. 131 Therefore, as far as we are aware, this is the first, and certainly largest quantitative, 132 systematic study of microalgae in the Delta, let alone Botswana. Given that the nature 133 of the flood pulse drives ecosystem functioning of this globally important wetland, 134 understanding relationships between hydrological drivers on primary producers and 135 diversity patterns is of the utmost importance.

\section{Methods}

\section{$\underline{\text { Site Selection }}$}

140 Sample points were selected with a view to maximising potential diatom responses to 141 hydrological variation (Fig 1). The upper Panhandle (UPH; $n=23$ ) is dominated by 142 fluvial input from the Okavango River, and is characterised by permanently flooded 143 habitats. Further downstream, the Okavango River meanders across the floodplain 144 into the lower Panhandle region ( $\mathrm{LPH} ; \mathrm{n}=27)$. As distance from the main channel 145 increases, seasonal swamps become more common, while old meanders result in the 146 formation and isolation of several large lagoons. South of the LPH, the presence of 147 numerous islands causes the Okavango River to split into separate distributaries 148 (Wolski and Murray-Hudson, 2006a). Just to the north of the Delta's largest island 149 (Chief's Island) the main distributary flows to the east forming the Maunachira / 150 Khwai river system, with many large, flow-through lagoons such as Xakanaxa (XAK; $151 \mathrm{n}=25$ ) (Fig 1). Secondary distributaries include the Jao / Boro river system (BOR; $152 \mathrm{n}=14$ ) and Santantadibe (SAN; n=7) (Fig 1). In 2006, Santantadibe flooded 153 extensively for the first time since the 1990s. Lake Ngami (NGA; n=2) sits at the end 154 of the Xudum distributary, and in recent decades very little water has flowed into the 155 lake. In 2004 however, floodwaters entered the lake for the first time since 1998.

156 Finally, two sample points were sampled from the Thamalakane river (THA; $n=2$ ), 157 which flows along the terminal edge of the Delta (Fig 1). 
160 Diatom samples were collected during the following dates: $1^{\text {st }}-9^{\text {th }}$ Sep 2006 (flood

161 recession; $\mathrm{n}=30$ ); $28^{\text {th }}$ Nov $-10^{\text {th }}$ Dec 2006 (low flood; $n=30$ ); $23^{\text {th }}$ Apr $-6^{\text {th }}$ May

1622007 (flood expansion; $n=31$ ); $24^{\text {th }} \mathrm{Jul}-7^{\text {th }}$ Aug 2007 (high flood; $n=9$ ). Habitats

163 investigated include marginal vegetation in channels (MV-IC), marginal vegetation in

164 lagoons (MV-L), floating vegetation (FV), inundated floodplains (IF) and isolated,

165 seasonally flooded pools (SP) (after Dallas and Mosepele, 2007). The first three

166 habitat types are permanently wet, while IF and SP experience wet-dry cycles. At

167 each sample point, 5-cm sections from characteristic dominant macrophyte species

168 were cut from desired plants c. $20 \mathrm{~cm}$ below the water surface (avoiding dead stems

169 and new shoots) and fixed with ethanol. The dominant habitat of each sample point

170 was recorded and geo-referenced using a Garmin GPS.

172 Diatoms were prepared for counting using standard techniques (Battarbee et al.,

173 2001). Sub-samples of plant stems were oxidised using $30 \% \mathrm{H}_{2} \mathrm{O}_{2}$ and carbonates

174 removed using 50\% $\mathrm{HCl}$. Permanent diatom slides were made using Naphrax and

175 duplicates archived both at UCL and University of Botswana. Diatoms were counted

176 using oil immersion phase contrast light microscopy at x1000 magnification. At least

177 350-400 valves were counted for each sample, and taxa identified with the assistance

178 of several flora (e.g. Cholnoky, 1966; Foged, 1966; Carter and Denny, 1982; Gasse,

179 1986; Krammer and Lange-Bertalot, 1999a; Krammer and Lange-Bertalot, 1999b;

180 Lange-Bertalot, 2001).

181

182 Diatom species adopt different growth forms (guilds) with which they are able to

183 respond to resource availability (e.g. nutrients, light) and disturbance (e.g. river flow,

184 grazing) (Biggs et al., 1998). Every diatom species was assigned to one of three

185 ecological guilds: low profile (guild 1), high profile (guild 2) or motile guild (guild 3)

186 (after Passy, 2007). Guild 1 diatoms attach themselves to substrates in prostrate,

187 adnate and erect forms (e.g. species in the genus Achnanthidium), but we also include

188 solitary centric species which do not form chains (e.g. species in the genus

189 Cyclotella), and slow moving species (e.g. species in the genus Amphora) which have

190 more in common with non-moving taxa than species that are able to move quickly

191 (Hudon and Legendre, 1987). Guild 2 diatoms include those that are tall in stature, or

192 form filamentous chains, or are composed of colonial centrics, e.g. species in the

193 genera Aulacoseira, Eunotia, Gomphonema. Guild 3 diatoms are relatively fast 
194 moving, low adhesive species (Passy, 2007), e.g. species in the genera Craticula, Navicula, Nitzschia.

Measures of diversity (Shannon and N2) were undertaken to determine if statistical differences existed between (i) different regions of the Delta, (ii) different stages of the flood cycle, and (iii) permanently wet and seasonally inundated sample points. Shannon index takes into account the number of species present and their evenness, while N2 diversity index relates to the effective number of species in a sample (ter Braak and Šmilaeur 2002). Shannon diversity analysis was undertaken using Past Version 2.08 (Hammer 2011). N2 diversity analysis was undertaken using C2 Data Analysis Version 1.5.1 (Juggins 2007).

\section{Collation of hydrological variables}

207 The influence of four hydrological variables (water depth, flow velocity, flood frequency and hydroperiod class) on diatom communities was initially explored for every sample point analysed for diatoms. Water depth was measured using a Plastimo Echotest II handheld depth sounder. Velocity of water flow was measured using an

211 OTT Nautilus C 2000 Electromagnetic Flow Sensor, which was designed to measure

212 water currents in the marginal zones of river banks, shallow water and waters with

213 low flow velocities. Annual flood frequency and hydroperiod class variables were

214 derived from remotely sensed images, hydrometric data and general understanding of

215 hydrological variability in the system. We used 16 data layers depicting maximum

216 annual inundation extent during years 1989-2006 (excluding 1991 and 2003). The

217 layers were obtained from Landsat (5 and ETM) images, using a classification

218 procedure involving spectral clustering and contextual classification (Wolski and

219 Murray-Hudson, 2006a). To depict the Delta, four Landsat scenes had to be

220 mosaicked for each coverage. Inundation layers had spatial resolution of 30 by $30 \mathrm{~m}$,

221 and 97\% accuracy of determination of inundation extent (Wolski and Murray-

222 Hudson, 2006a). Dates of the imagery were selected to coincide with the period of 223 maximum, annual inundation. The flooding in the Delta takes the form of a single,

224 annual event with progressive transition between low inundation and high inundation

225 taking place throughout a year. Earlier work, with weekly NOAA AVHRR images,

226 revealed that the crest of the flood lasts approximately 1-2 months in distal parts, but

227 3-4 months in the proximal parts of the Delta proper, and fast recession occurs only in 
228 October (Wolski and Murray-Hudson, 2006b). Based on these findings, Landsat

229 scenes from end of August to mid-September were selected for high-resolution

230 inundation mapping. Number of years inundation occurred was calculated for the

231 entire Delta on a pixel-by-pixel basis, by stacking up all individual layers. Flood

232 frequency was then obtained by dividing number of years with inundation by the total

233 number of flood maps. Flood frequency for each of the sampling points was obtained

234 by averaging flood frequency from the nine surrounding pixels, corresponding to the

235 sampling point, using neighbourhood statistics procedure. This was done to reduce

236 possible influence of errors resulting from image misclassification and

237 misregistration. In the seasonally inundated parts of the Delta, annual inundation

238 frequency can be considered as a proxy for mean duration of inundation. This results

239 from the nature of the flood event where parts of the system are likely to be inundated

240 longer only in high flood years, for a short term only in moderate years, and not

241 inundated at all in low flood years. However, the relationship between the amplitude

242 of annual water level fluctuations and flood frequency varies for different parts of the

243 system. Available hydrometric data were not enough to formalize these relationships

244 in strict mathematical form; only around 30 hydrometric stations exist in the Delta,

245 approximately 1 per $400 \mathrm{~km}^{2}$. Instead, a set of seven hydroperiod/amplitude classes

246 was defined, and a hydroperiod class was attached to each of the sample points. The

247 hydroperiod class gradient spans sample points selected from permanently flooded

248 regions with low amplitude (under $0.3 \mathrm{~m}$; Class 7) to samples points selected from

249 newly inundated drylands (Class 1). Classes 6 and 5 were also permanently flooded

250 regions, but flood amplitude varied between $0.3-1.0 \mathrm{~m}$ and $1.0-3.0 \mathrm{~m}$ respectively.

251 Sampling points allocated to class 4 and 3 have, since 2004, been flooded every year,

252 but over the longer term (20 years) were once only seasonally flooded, with flood

253 duration in class 4 longer than class 3. Class 2 sample points were only seasonally

254 flooded for under 6 months of the year. The classification was based on flood

255 frequency maps and hydrometric data from hydrometric stations in the vicinity of

256 sampling point.

258 Collation of hydrochemical variables

259 Surface water chemistry variables are only available for selected diatom sample

260 points during Dec06, May07 and Jul07 trips ( $\mathrm{n}=53)$. $\mathrm{pH}$ and conductivity $\left(\mu \mathrm{S} \mathrm{cm}^{-1}\right)$ 
261 were measured in situ using a portable Fisher Scientific Accumet AP85 portable waterproof $\mathrm{pH} /$ conductivity meter. $250 \mathrm{ml}$ of Delta water were filtered through a GF/C filter into acid-washed bottles for non-metal $\left(\mathrm{HCO}_{3}, \mathrm{Cl}, \mathrm{SO}_{4}\right.$, dissolved organic carbon (DOC)) analyses. $250 \mathrm{ml}$ of water were also filtered using cellulose nitrate papers for cation analyses $(\mathrm{Na}, \mathrm{K}, \mathrm{Mg})$ and immediately acidified with three drops of concentrated $\mathrm{HNO}_{3}$. A further $250 \mathrm{ml}$ of water was filtered using cellulose nitrate filter papers for $\mathrm{SiO}_{2}$ analysis. All filtered samples were stored in acid-washed plastic sample bottles in cool-boxes, with bags of ice, then transported to the Okavango Research Institute. $\mathrm{HCO}_{3}$ was determined within $48 \mathrm{~h}$ of sample collection. DOC and anions were analysed within 7 days, while TN and TP were determined within three weeks of collection. Metals were analysed within 2 months after collection. Determination of $\mathrm{Mg}\left(\mathrm{mg} \mathrm{L}^{-1}\right)$ was undertaken by flame atomic absorption spectrometry using a Varion Spectra 220 instrument. Lanthanum was used as a releasing agent to reduce interferences during $\mathrm{Ca}$ analysis (Eaton et al. 1995). $\mathrm{Na}$ (mg $\left.\mathrm{L}^{-1}\right)$ and $\mathrm{K}\left(\mathrm{mg} \mathrm{L}^{-1}\right)$ were determined by flame photometry using a Sherwood Flame Photometer 410 instrument. $\mathrm{HCO}_{3}\left(\mathrm{mg} \mathrm{L}^{-1}\right)$ was analysed using an auto-titrator (Mettler Toledo model DL 50). $\mathrm{Cl}\left(\mathrm{mg} \mathrm{L}^{-1}\right)$ and $\mathrm{SO}_{4}\left(\mathrm{mg} \mathrm{L}^{-1}\right)$ were analysed by ion chromatography using a $D X-120$ ion chromatograph (Eaton et al. 1995). An approximation of DOC $\left(\mathrm{mg} \mathrm{L}^{-1}\right)$ was obtained by measuring the absorbance of the water samples at $280 \mathrm{~nm}$ using a Perkin Elmer Lamda 20 UV/Vis spectrophotometer

\section{$\underline{\text { Statistical Analyses }}$}

288 Cluster analysis using two-way indicator species analysis (TWINSPAN) was undertaken to determine broad patterns in diatom community composition (Hill, 1979). Species occurring in relative abundances $<1 \%$, or $<3$ sites were excluded

291 from analyses, because they had little effect on derived groupings. Patterns in diatom 292 community composition were initially analysed using the indirect, ordination 293 technique of detrended correspondence analysis in order to determine whether species 294 responses were mainly linear or unimodal. The axis 1 gradient length was 2.218 
295 standard deviation units, indicating that linear ordination methods were most appropriate for our datasets (Lepš and Šmilaeur, 2003). Derived clusters were then used to classify sites analysed using principal components analysis (PCA), with symmetric scaling of the ordination scores to optimise scaling for both samples and species. Species data were $\log (x+1)$ transformed and both species and samples were centred to give a log-linear contrast PCA, appropriate for closed, relative abundance data (Lotter et al. 1993). A broken stick model was sued to test the significance of the PCA axes (Joliffer 1986) using BSTICK v.1.0 (Line and Birks 1996). A ‘crisp' classification (where sites belonging to a particular TWINSPAN group are coded 1 or 0 ) was determined in order that Fisher's linear discriminant analysis (LDA) could be undertaken to assess the influence of (i) hydrological variables and (ii) guild structure on the classes defined by TWINSPAN (Lepš and Šmilaeur, 2003). LDA was undertaken using canonical correspondence analysis (focusing on species distances and using Hill's scaling) in Canoco 4.5 (Lepš and Šmilaeur, 2003).

310 Hydrological influences on diatom species composition across 100 sample points was 311 determined using redundancy analysis (RDA). Initially, the explanatory power and 312 significance of each hydrological variable was determined through a series of single 313 constrained RDAs, together with Monte Carlo permutation tests $(\mathrm{p}=0.002 ; \mathrm{n}=499)$.

314 The unique contribution of each variable was then assessed through a series of partial 315 RDAs with the remaining hydrological variables as covariables. Exactly one-fifth of 316 the sample points $(n=20)$ were visited on more than one occasion. Consequently, a 317 partial RDA with season as covariable was undertaken, together with Monte Carlo 318 permutation tests $(\mathrm{p}=0.002 ; \mathrm{n}=499)$. A major feature of spatial datasets such as ours 319 is the influence of sample point proximity (Legendre, 1993). Here we explore this 320 influence by partialling out sample point location co-ordinates using RDA. In order to 321 identify a minimum subset of variables that significantly explain variation in the 322 diatom data, redundant variables were removed through a form of step-wise 323 regression (forward selection) together with Monte Carlo permutation tests ( $\mathrm{p}=$ 324 0.002; $\mathrm{n}=499$ ) and associated Bonferroni corrections (ter Braak and Šmilaeur, 2002).

325 Species response curves for selected taxa to hydroperiod class were explored using 326 generalized additive models (GAMs). Poisson distributions were selected and 327 binomial total settings used maximum values. Significance of diatom responses to 328 hydroperiod class were assessed using Akaike Information Criterion (AIC) to 
329 determine the parsimony of response models constructed. Prior to all analyses

330 explanatory variables were tested for normality and were subsequently $\log (x+1)$

331 transformed (except $\mathrm{pH}$ ). Ordination analyses were undertaken using Canoco v. 4.5

332 (Lepš and Šmilaeur, 2003). GAMs were undertaken using Canodraw for Windows 4.1

333 (Lepš and Šmilaeur, 2003).

334

335 Differences in diversity measures were analysed using SPSS 17.0. Levene's tests for

336 equality of variances were undertaken to ensure that appropriate parametric and non-

337 parametric tests were used. Regional diversity indices had equal variance and were

338 analysed using analysis of variance (ANOVA), and differences between the regions

339 were further investigated using post-hoc tests with Bonferroni corrections. Flood-

340 stage diversity indices had unequal variance, and were analysed using Kruskal-Wallis

341 (KW) tests. KW has no equivalent post-hoc test, so where the KW test did reveal

342 significant variation, pairwise Mann-Whitney U tests were undertaken to determine

343 significant differences between stages of the flood cycle. Differences between sites

344 that were permanently or seasonally flooded, were analysed using a 2-tailed t-test.

\section{Results}

348 Full names, taxonomic authorities, Hill's N2 diversity and maximum abundance of 349 each of the 167 species are detailed in Appendix S1 in Supplementary Information. 350 Two-way indicator species analysis revealed six distinct groups (Table 1). Group 1

351 consists only of sample points visited in the upper Panhandle during May 2007, which

352 LDA reveals to be associated with deep-water sites with high flow velocities and is 353 dominated by species with guild 1 (low) growth form (Fig 2). Group 2 consists of 354 sample points from each of the four main regions with highest hydroperiod class and 355 diatoms with guild 2 (high) growth form. Sample points in group 3 were sampled 356 during flood recession and low flood (except for Thamalakane) in waters with low 357 flow velocity (Fig 2a), while sample points in group 4 were mainly sampled during 358 flood expansion and peak flood. Diatom guilds are distinctly different in these two 359 groups, with guild 2 diatoms dominating group 4 (Fig 2b). Group 5 consists of sample 360 points not sampled during peak flow, while group 6 consists only of sample points in 361 the Boro and Xakanaka regions during flood expansion (Table 1). Both groups are 
362 best characterised by shallow, low hydroperiod class sample points, and diatoms dominated by motile species in guild 3 (Fig 2a,b).

The first two PCA axes account for $15.2 \%$ and $12.1 \% \%$ of variation in the species data respectively. Broken stick reveals both these values to be significant (Table 2). Samples in the PCA biplot (axes 1 and 2) have been classified according to their TWINSPAN groupings (Fig 3). Axis 1 represents an environmental gradient with groups 5 and 6 at one end, characterised by seasonally inundated floodplains and pools $(\mathrm{IF}+\mathrm{SP})$. The other end of the gradient is characterised by permanently inundated sample points (e.g. in group 2) with highest hydroperiod class (MV+FV). The four hydrological variables significantly explain $10 \%$ of total diatom variation that cannot be explained by site proximity (Table 3). However, unique variation explained by each variable is also significant, as is variation when season is partialled out as a co-variable (Table 4). In each of these analyses, hydroperiod class remains the variable that significantly explains most variation in the diatom data. In the reduced dataset with both hydrology and hydrochemistry as explanatory variables (Table 5), $\mathrm{K}^{+}$and $\mathrm{Mg}^{2+}$ displayed high variance inflation factors, indicating a substantial amount of collinearity (ter Braak and Šmilaeur, 2002) and were excluded from analyses. Constrained ordination using forward selection determined five variables significantly accounted for almost $30 \%$ of the variation in the diatom dataset (Table 6). Axis 1 is controlled mainly by the gradient between diatoms associated with high hydroperiod class and flood frequency, and diatoms associated with nutrients, $\mathrm{TN}$ and $\mathrm{SiO}_{2}$ (Fig 4). Species highly correlated along this axis are similar in composition to PCA determined above. Species composition along axis 2 is different however, and is now primarily characterised by species associated along a flow velocity gradient (Fig 4).

Selected diatom response curves for hydroperiod class have been grouped together according to their guilds (Fig 5). Guild 1 diatoms in general show skewed unimodal responses (Fig 5a). Guild 2 diatoms show a heterogeneous set of responses (Fig 5b, c). Several species however did not exhibit any significant response curves: Synedra acus v. acus and Staurosirella pinnata have rather flat null responses, whereas

394 Eunotia pectinalis v. minor shows an increasing trend which does not reach a maximum value. Guild 3 species generally display declining monotonic responses, 
although the response for Nitzschia bacata is rather more complex, while that for Navicula cryptotenella shows no significant trend. (Fig 5d).

Between regions, only Shannon index shows significant variation $(\mathrm{p}=0.002)$, with sample points in the UPH region having higher values than either LPH $(\mathrm{p}=0.001)$ or BOR ( $\mathrm{p}=0.012$ ). Both Shannon and N2 indices exhibited significant variation in relation to different stages of the flood cycle: lowest values were recorded during high flood, and these values were statistically lower than during each of the other stages. Neither Shannon $(\mathrm{p}=0.623)$ nor $\mathrm{N} 2(\mathrm{p}=0.815)$ indices showed any significant difference between permanently flooded and seasonally inundated sample points.

\section{Discussion}

Spatial trends in diatom communities in the Okavango Delta

410 Hydrology and surface water chemistry are influential in determining ecological

411 guilds and species community composition in the Okavango Delta. The most

412 important pattern is the significant gradient between species that inhabit seasonally

413 inundated floodplains and pools, and species which show greater preference for

414 permanently inundated sites. Species with high positive PCA axis 1 correlations

415 (found mainly in groups 5 and 6; Fig 3) exhibit several adaptations that allow them to 416 colonise seasonally inundated habitats. Craticula buderi, Sellaphora pupula and

417 Navicula cryptotenella are highly motile and therefore competitive with regard to 418 both disturbance pressures and limited resources (Passy, 2007). Species such as 419 Nitzschia bacata and Nitzschia communis are adapted to growing in seasonally wet 420 habitats (Gasse, 1986) and are obligate N-heterotrophs (van Dam et al., 1994) that 421 need continuously elevated concentrations of organically bound nitrogen to thrive. 422 Other species grow best in slow moving waters e.g. S. acus v. tenera (Patrick and 423 Reimer, 1966). Craticula buderi and Cyclotella meneghiniana can tolerate brackish 424 waters while other species thrive when soil surfaces are only periodically inundated 425 (e.g. Pinnularia gibba) (van Dam et al., 1994). Hantzschia amphioxis is an 426 aerophilous species that can tolerate drying, and in our study, this species was only 427 found in the recently flooded regions of Santantadibe and Lake Ngami. Motile 428 diatoms such as those found in groups 5 and 6 are classed as epipelon, and inhabit the 429 soft surface sediments of the floodplains. Epipelon help to mediate efflux rates of 
430 nutrients from sediment interstitial water (Goldsborough and Robinson, 1996), and

431 therefore influence nutrient status of surface waters.

432

433 Species with high negative PCA axis 1 scores occur in permanently inundated sites.

434 These species are commonly $\mathrm{N}$-autotrophs and grow best in well-aerated, oligotrophic

435 environments, e.g. Achnanthidium minutissimum, Eunotia naegelli and Eunotia

436 rhomboidea. Achnanthidium minutissimum is sensitive to organic pollution and

437 nutrient enrichment, and so axis 1 also likely represents a nutrient gradient, linked to

438 frequency of inundation. The gradient along PCA axis 2 largely represents a split

439 between TWINSPAN group 3 and groups 1, 2 and 4. Nitzschia amphibia is a

440 facultative N-heterotroph, and so periodically needs elevated concentrations of

441 organically bound nitrogen (van Dam et al., 1994). In contrast, Cymbella leptoceros is

442 an N-autotroph, while Rhopalodia gibba is able to fix its own nitrogen via spheroidal

443 bodies which likely have cyanobacterial origin (Prechtl et al., 2004). Eunotia

444 pectinalis v. minor and Eunotia flexuosa species are also $\mathrm{N}$-autotrophs and grow best

445 in circumneutral, low alkalinity environments (Patrick and Reimer, 1966). Axis 2

446 therefore is unlikely to represent a simple nutrient gradient.

$448 \quad$ Factors driving observed spatial trends

449 The flood-pulse nature of the Delta results in surface water chemistry being associated

450 with hydrological drivers. For example, RDA reveals that sites of low hydroperiod

451 class, i.e. those that are seasonally inundated, have elevated concentrations of key

452 nutrients such as $\mathrm{TN}$ and $\mathrm{SiO}_{2}$ (Table 2; Fig 4). Cations and anions are between c. 2-3

453 times greater in the distal regions (e.g. Boro river system) than the upper Panhandle

454 (Cronberg et al., 1996; Mackay et al., in review). These differences are mainly caused

455 by the greater area of seasonally inundated floodplains (Krah et al., 2006) and by

456 evapotranspiration processes (Dinçer et al., 1978). Generally, motile species exhibit

457 monotonic (declining) responses to increasing hydroperiod class (Fig 5). Floodplain

458 nutrients come from a number of sources including river flow (Cronberg et al., 1996),

459 windblown dust (Krah et al., 2006), animal faeces (Lindholm et al., 2007) and from

460 within the wetland sediments themselves which have accumulated nutrients over

461 thousands of years (Mendelesohn et al., 2010). 
463 Nitrogen and phosphorous can limit plant growth, which makes them the two most

464 important wetland macronutrients. Perhaps surprisingly, our analyses indicate that TP 465 has no significant impact on diatom community composition (Table 6). TN however 466 does significantly influence diatom variation across the Delta (Table 6). Highest TN 467 concentrations are associated with seasonally inundated floodplains in the Boro and 468 Xakanaka regions sampled during the period of flood expansion. The high 469 concentration of TN present in the floodplains allows for the proliferation obligate 470 and facultative N-heterotrophs such as Nitzschia bacata and Nitzschia amphibia 471 respectively (Fig 4). Species which are very sensitive to excess nitrogen enrichment, 472 such as Achnanthidium minutissimum, conversely are most abundant in sites with very 473 low concentrations of TN (Fig 4), while the species response curve for Achnanthidium 474 minutissmum shows that it grows optimally in sites with high hydroperiod class (Fig 475 5). The susceptibility of aquatic ecosystems to algal blooms can be assessed by 476 determining TN/TP ratios. Small ratios (e.g. under 10) can suggest elevated supply of 477 phosphorus, whereas pristine environments (where $\mathrm{P}$ is likely to be limiting) are more 478 likely to have ratios $>15$ (Hecky and Kilham, 1988). TN/TP ratio for TWINSPAN groups 5 and 6 together is 38, while for TWINSPAN groups 1-4 together, the ratio is much lower at 14. The high ratio in groups 5 and 6 is above the minimum for 481 limitation for P (Cronberg et al., 1996). However, the relatively low value for the 482 remaining sites is unlikely to be due to elevated concentrations of TP (which we have 483 established are low throughout the Delta), but most likely due to a number of 484 processes including intensive denitrification (a major factor for $\mathrm{N}$ loss from wetland 485 soils (Reddy and Patrick, 1984; Mitsch and Gosselink, 2000)), the coupling of P with sediment loads (Cronberg et al., 1996) and uptake by aquatic macrophytes.

$\mathrm{SiO}_{2}$ is an essential component of diatom metabolism, and highest concentrations are found in the seasonally inundated floodplains and pools. Increasing $\mathrm{SiO}_{2}$ concentrations are most highly correlated with increasing abundances in several diatom species, including Aulacoseira granulata, Pinnularia gibba, Synedra acus v. tenera, Craticula buderi. Species such as Aulacoseira granulata require high concentrations of $\mathrm{SiO}_{2}$ for valve development. For other species however, it is not clear whether they are growing well due to high concentrations of $\mathrm{SiO}_{2}$, or whether they are responding more to other factors such as elevated TN, or even simply periodic wetting of the habitat. Species which grow best in very slow moving, nutrient 
497 rich waters include Gomphonema parvulum, Aulacoseira distans v. africana and 498 Aulacoseira ambigua. All three species have high profile growth forms and so are 499 able to tolerate the low flow velocities impacting those sites (Fig 4). Gomphonema 500 parvulum, is a facultative $\mathrm{N}$-heterotroph, and although it has a broad tolerance to 501 nutrients it grows best when nutrients are elevated (van Dam et al., 1994). Like 502 Aulacoseira granulata, Aulacoseira distans v. africana and Aulacoseira ambigua 503 require high concentrations of $\mathrm{SiO}_{2}$. In East African lakes, Gasse (1986) found that 504 Aulacoseira ambigua and Aulacoseira distans v. africana grew best in shallow waters 505 dominated by Ca-Mg carbonates, colonized by swampy vegetation (habitats very like 506 the distal regions of the Delta).

508 Diatom species associated with high hydroperiod class include Achnanthidium 509 minutissimum, Eunotia pectinalis v. minor and Navicula radiosa, each of which 510 represents a different guild (low, high and motile respectively). This is perhaps not 511 surprising as the vectors for hydroperiod class and velocity are orthogonal to each 512 other (Fig 4), so the diatoms associated with increasing hydroperiod class will not 513 necessarily show any trend with increasing velocity (i.e. growth form). In the 514 Panhandle region there are many lagoons, which although deep also have very little 515 flow. Both Navicula radiosa and Achnanthidium minutissimum require well aerated, 516 highly oxygenated waters (Cholnoky, 1966; Gasse, 1986; van Dam et al., 1994), 517 which ties in well with their occurrence in waters which are permanently inundated, 518 but whose environments do not become shallow or stagnant. Eunotia naegelli, 519 Eunotia rhomboidea, Synedra amphicephela and Gomphonema gracile exhibit high 520 profile growth forms, and are able to flourish when disturbance pressures such as high 521 velocities are low. Gomphonema gracile for example also shows high affinity with 522 rather stagnant waters in the East African great lakes (Gasse, 1986), but is intolerant 523 of elevated nitrogen concentrations (van Dam et al., 1994). Species in the Eunotia 524 genus however exhibit highest abundances when hydroperiod classes are high (Fig

525 5b). Eunotia species are all $\mathrm{N}$ autotrophs, and therefore not dependent on high 526 nitrogen concentrations. The exception here is Eunotia okawangoi. It grows best in 527 seasonally inundated floodplains with low hydroperiod class (Fig 5b). Further work is 528 needed to better characterise this species ecological requirements. 
530 Diatom species associated with high flow velocities include group 1 indicator taxa

531 Frustulia crassivervia and Brachysira brebissoni (Table 1), Eunotia pectinalis v.

532 undulata, Synedra acus v. acus, Encyonema mesiana, Encyonema minuta and

533 Encyonema gracilis (Fig 4). Group 1 sites are generally taken from deep channel

534 margins along the southern most reaches of the Okavango River. Many diatom

535 species here exhibit low profile growth forms (guild 1). For example, Encyonema

536 species grow in mucilaginous communities and are able to tolerate relatively high

537 flow velocities (Biggs et al., 1998) such as those in the UPH.

The Shannon index is a function of both species richness and evenness, i.e. the

540 distribution of individuals among species. Significantly high values of Shannon index

541 in the UPH suggests that diatom communities in this region contain many taxa which

542 have few individuals, especially in comparison to communities in LPH and BOR

543 regions. High diversity values may be interpreted in the context of the intermediate

544 disturbance hypothesis (IDH) (Connell 1978), such that moderate levels of

545 disturbance can prevent competitive exclusion. Diversity can also be interpreted

546 within the context of resource-competition theory. For example, high algal diversity

547 can be associated with conditions where many resources are limiting (e.g. Interlandi

548 and Kilham 2001). The fast flowing waters in the UPH therefore may result in

549 sufficient disturbance to maintain high diatom diversity. These relationships are

550 apparent in both Table 1 and axis 2 in RDA (Fig 4). The RDA biplot also reveals a

551 negative association between high velocity and $\mathrm{TN}$ and $\mathrm{SiO}_{2}$, i.e. such that key

552 nutrients at these sample points were also lowest, which conforms to findings by

553 Interlandi and Kilman 2001). Significantly lower diversity values during peak flood

554 suggest that fewer taxa dominate communities, such as Achnanthidium minutissimum,

555 which is abundant in regions with high hydroperiod class (Fig 5). Our data may

556 suggest therefore that at this stage in the flood cycle, few resources are limiting, and

557 levels of disturbance low. In a recent comprehensive study of surface water chemistry

558 across the Delta, Mackay et al. (in review) showed that TN concentrations were

559 significantly highest during peak flood, which fits well with the hypothesis that key

560 nutrients at this time were not limiting (Interlandi and Kilman 2001).

562 It was also hypothesised that seasonally inundated sample points would contain

563 higher levels of diatom diversity than permanently inundated sample points due to the 
564 intermediate disturbance hypothesis (Connell 1978). However, no statistical

565 difference in diatom diversity was found between these two groups of sample points.

566 This may be because the rate of inundation is very slow, and diatom communities are

567 adapted to exploiting available niches quickly, or that there is no difference in

568 resource limitation between either permanently or seasonally flooded habitats. Our

569 data certainly show different communities living in the two groups of sample points,

570 but the gradual inundation has not resulted in shifts between e.g. stress tolerant and

571 stress sensitive species (Stevenson 1997). However, other factors may also play a

572 role, such as grazing by zooplankton and macroinvertebrates (Jones and Sayer 2003),

573 because consumer diversity at this time is highest (unpublished data). Future work

574 will explore these concepts in more detail.

576 Modelled impacts of changing hydrology from increasing development in the ORB

577 are relatively small in comparison to observed variability in river flow in recent

578 decades and modelled variability forced by predicted future climate change (Murray-

579 Hudson et al., 2006). The size of the flood pulse in the Delta has increased over the

580 last five years, and is likely to continue to increase into the near future due to a quasi,

581 80-year, climatic oscillation (Gumbricht et al. 2004). However, over the next 100

582 years, climate change scenarios in southwest Africa are still highly uncertain (Hughes

583 et al. 2010). A key question therefore remains as to how an increase in volume of

584 water in the flood pulse will influence diatom communities in the Delta. From our

585 analyses, changes in the extent of inundated floodplains will have a significant impact

586 on the composition of diatom communities related to, e.g. nutrient availability,

587 although determining the impacts on diatom diversity needs further work.

588

589 Conclusions

590

591 Hydrological variability may be a deciding factor in biogeochemical cycling in flood-

592 pulse wetlands (Struyf and Conley, 2009), and it certainly influences surface water

593 chemistry and habitat availability for many organisms. This is the first study to model

594 diatom responses to hydrological and hydrochemical variability in the Okavango

595 Delta. As such, this study forms an important baseline for future work into

596 biogeochemical cycling in the Delta and food-web interactions between species

597 highly adapted to seasonally inundated floodplain environments and species 
598 recognised for their international conservation value. We have also demonstrated that

599 diatoms in the Delta are sensitive to surface water chemistry, including nutrients such

600 as $\mathrm{TN}$ and $\mathrm{SiO}_{2}$. Diatoms therefore have the potential to make excellent sensors of

601 environmental change for current and future biomonitoring programmes as long as

602 hydrological variability is also considered. Diatoms would, for example, be amongst

603 the first organisms to respond to any future deterioration in water quality. Ecosystem

604 health of the Delta is also under threat from future climate variability and hydro-

605 technological development, which would attenuate the nature of the flood pulse.

606 However, not only would this alter the availability of substratum for microalgae to

607 grow, but any decline in flow would also have a detrimental effect on growth and

608 primary production (Goldsborough and Robinson, 1996). Such changes could have

609 severe negative consequences for the ecosystem functioning of this globally important 610 wetland. 


\section{References}

614

615 Andersson L, Wilk J, Todd MC, Hughes DA, Earle A, Kniveton, D Layberry, R,

616 Savenije HHG. 2006. Impact of climate change and development scenarios on flow

617 patterns in the Okavango River. Journal of Hydrology 331 : 43-57.

618

619 Ashton PJ. 2002. Avoiding conflicts over Africa's water resources. Ambio 31 : 236620242.

621

622 Battarbee RW, Carvalho L, Jones VJ, Flower RJ, Cameron NG, Bennion H, Juggins

623 S. 2001. Diatoms. (ed. By J.P. Smol, W. Last and H.J.B. Birks), pp. 155- 202.

624 Kluwer Academic Publishers, Dordrecht.

625

626 Biggs BJF, Goring DG, Nikora VI. 1998. Subsidy and stress responses of stream

627 periphyton to gradients in water velocity as a function of community growth form.

628 Journal of Phycology 34 : 598-607.

629

630 Carter JR, Denny P. 1982. Freshwater algae of Sierra Leone. HI. [sic, part IV]

631 Bacillariophycaeae: Part (i) diatoms from the River Jong (Taia) at Njala. Nova

632 Hedwigia, Beiheft $73: 281-331$.

633

634 Connell JH. 1978. Diversity in tropical rain forests and coral reefs. Science 199 :

$635 \quad 1302-1310$.

636

637 Cholnoky BJ. 1966. Die Diatomeen im Unterlaufe des Okawango-Flusse. In:

638 Diatomaceae I. Nova Hedwigia Heft 21 : 1-122.

639

640 Cronberg G, Gieske A, Martins E, Prince Nengu J, Stenström I-M. 1996. Major ion

641 chemistry, plankton, and bacterial assemblages of the Jao/Boro River, Okavango

642 Delta, Botswana: the swamps and floodplains. Archiv für Hydrobiologie 107 : 335 -

643407.

644

645 Dallas H, Mosepele B. 2007. A preliminary survey and analysis of the spatial 
646 distribution of aquatic invertebrates in the Okavango Delta, Botswana. African Journal of Aquatic Science 32 : 1-11.

648

649 Dinçer T, Hutton, LG, Khupe, BBJ. 1978. Study, using stable isotopes, of flow

650 distribution, surface-groundwater relations and evapotranspiration in the Okavango

651 Swamp, Botswana. Isotope Hydrology, Proceedings of a Symposium, Neuherberg 652 IAEA, 3-36.

653

654

Eaton AD, Clesceri SL, Greenberg EA. 1995. Standard methods for the Examination of water and wastewater. American Public Health Association, Washington DC.

656

657

Foged N. 1966. Freshwater diatoms from Ghana. Biol. Skr. Dan. Vid. Selsk.

658

(Biologiske Skrifter $\left(4^{\circ}\right)$ (Biologie)) 15 : $161 \mathrm{pp.}$

659

660

Gasse F. 1986. East African diatoms: taxonomy, ecological distribution. Bibliotheca

661 Diatomologica, Band 11. J. Cramer, Berlin.

662

663 Gell PA, Sluiter IR, Fluin, J. 2002. Seasonal and interannual variations in diatom

664 assemblages in Murray River connected wetlands in north-west Victoria Australia.

665 Marine and Freshwater Research 53 : 981-992.

666

667 Goldsborough LG, Robinson GGC. 1996. Patterns in Wetlands. (ed by R.J.

668 Stevenson, M.L. Bothwell and R.L. Lowe) pp 77-117. Academic Press, San Diego. 669

670 Gumbricht T, Wolski P, Frost P, McCarthy TS. 2004. Forecasting the spatial extent of 671 the annual flood in the Okavango Delta, Botswana. Journal of Hydrology 290 : 178672191.

673

674 Hammer Ø. 2011. Past: Paleontological Statistics Reference Manual. Version 2.08. 675

676 Hecky RE, Kilham P. 1988. Nutrient limitation of phytoplankton in freshwater and 677 marine environments: a review of recent evidence on the effects of enrichment.

678 Limnology \& Oceanography 33 : 796-822. 
680 Hill MO. 1979. TWINSPAN - a FORTRAN program for arranging multivariate data

681 in an ordered two-way table by classification of the individuals and attributes.

682 Ecology and Systematics, Cornell University, Ithaca, New York.

683

684 Hudon C, Legendre P. 1987. The ecological implications of growth forms in

685 epibenthic diatoms. Journal of Phycology 23 : 434-441.

686

687 Hughes DA, Kingston DG, Todd MC. 2010. Uncertainty in water resources

688 availability in the Okavango River Basin as a result of climate change. Hydrology and

689 Earth System Sciences 7 : 5737-5768.

690

691 Interlandi SJ, Kilham S. 2001. Limiting resources and the regulation of diversity in

692 phytoplankton communities. Ecology 82 : 1270-1282.

693

694 Jollifer, IT. 1986. Principal components analysis. Springer-Verlag, New York, 271 pp

695

696 Jones JI, Sayer CD. 2003. Does the fish-invertebrate-periphyton cascade precipitate

697 plant loss in shallow lakes? Ecology 84 : 2155-2167.

698

699 Juggins. S. 2007. C2 Version 1.5 User guide. Software for ecological and

700 palaeoecological data analysis and visualisation. Newcastle University, Newcastle

701 upon Tyne, UK. 73pp

702

703 Junk WJ, Bayley PB, Sparks RE. 1989. The flood pulse concept in river-floodplain

704 systems. Canadian Journal of Fisheries \& Aquatic Sciences 106 : 110-127.

705

706 Junk WJ, Brown M, Campbell IC, Finlayson M, Gopal B, Ramberg L, Warner, BG.

707 2006. The comparative biodiversity of seven globally important wetlands: a synthesis.

708 Aquatic Sciences 68 : 400-414.

709

710 Kgathi DL, Kniveton D, Ringrose S, Turton AR, Vanderpost CHM, Lundqvist J,

711 Seely M. 2006. The Okavango: a river supporting its people, environment and

712 economic development. Journal of Hydrology 331 : 3-17. 
714 Krah M, McCarthy TS, Huntsman-Mapila P, Wolski P, Annegarn H, Sethebe K.

715 2006. Nutrient budget in the seasonal wetland of the Okavango Delta, Botswana.

716 Wetland Ecology \& Management 14 : 253-267.

717

718 Krammer K, Lange-Bertalot H. 1999a. Bacillariophyceae. 1. Teil: Naviculaceae. (ed

719 by H. Ettl, J. Gerloff, H. Heynig, D. Mollenhauer), pp. 876. Akademischer Verlag

720 Heidelberg, Berlin.

721

722

Krammer K, Lange-Bertalot H. 1999b. Bacillariophyceae. 2. Teil: Bacillariaceae,

723

Epithemiaceae, Surirellaceae. (ed by H. Ettl, J. Gerloff, H. Heynig, D. Mollenhauer),

724 pp. 596. Akademischer Verlag Heidelberg, Berlin.

725

726

Lane CR, Brown MT. 2007. Diatoms as indicators of isolated herbaceous wetland 728

729 condition in Florida, USA. Ecological Indicators 7 : 521-540.

730

Lange-Bertalot H. 2001. Diatoms of Europe, Volume 2: Navicula sensu stricto. 10 genera separated from Navicula sensu lato Frustulia. (Ed by H. Lange- Bertalot)

732

733 A.R.G. Gantner Verlag, Berlin.

Legendre P. 1993. Spatial autocorrelation: trouble or new paradigm? Ecology 74 :

734 1659-1673.

735

736

Lepš J, Šmilaeur P. 2003. Multivariate analysis of ecological data using CANOCO.

CUP, Cambridge.

Lindholm M, Hessen DO, Mosepele K, Wolski P. 2007. Food webs and energy fluxes on a seasonal floodplain: the influence of flood size. Wetlands 27 : 775-784.

Line JM, Birks HJB. 1996. BSTICK Version 1.0. Unpublished computer program.

743 Botanical Institute, University of Bergen. 
749 Mackay AW, Davidson T, Wolski P, Mazebedi R, Masamba WRL, Huntsman-Mapila

750 P, Todd, M. in review. Spatial and seasonal variability in surface water chemistry in

751 the Okavango Delta, Botswana: a multivariate approach. Wetlands

752

753 McCarthy JM, Gumbricht T, McCarthy T, Frost P, Wessels K, Seidel F. 2003.

754 Flooding patterns of the Okavango Wetland in Botswana between 1972 and 2000.

755 Ambio 32 : 453-457.

756

757 McCormick PV, Stevenson RJ. 1998. Periphyton as a tool for ecological assessment 758 and management in the Florida Everglades. Journal of Phycology 34 : 726-733.

760 Mendelsohn JM, Vanderpost C, Ramberg L, Murray-Hudson M, Wolski P, Mosepele 761 K. 2010. Okavango Delta: floods of life. RAISON, Windhoek Namibia.

762

763 Millennium Ecosystem Assessment 2005. Ecosystems and human well-being:

764 wetlands and water. Synthesis. World Resources Institute, Washington DC.

765

766 Mitsch WJ, Gosselink JG. 2000. Wetlands. $3^{\text {rd }}$ Edition. John Wiley and Sons, New 767 York.

768

769 Mladenov N, McKnight DM, Wolski P, Ramberg, L. 2005. Effects of the annual

770 flood on dissolved organic carbon dynamics in the Okavango Delta Botswana.

771 Wetlands 25 : 622-638.

772

773 Murray-Hudson M, Wolski P, Ringrose, S. 2006. Scenarios of the impact of local and

774 upstream changes in climate and water use on hydro-ecology in the Okavango Delta,

775 Botswana. Journal of Hydrology 331 : 73-84.

776

777 Passy SI. 2007. Diatom ecological guilds display distinct and predictable behaviour

778 along nutrient and disturbance gradients in running waters. Aquatic Botany 86 : 171 779178. 
781 Patrick R, Reimer CW. 1966. The diatoms of the United States: volume 1. Monograph

782 series of the Academy of Natural Sciences of Philidelphia, No. 134.

783

784 Pinheiro I, Gabaake G, Heyns P. 2003. Cooperation in the Okavango River Basin: the 785 OKACOM perspective. (ed by A.R. Turton, P. Ashton and E. Cloete). pp 105-139. 786 African Water Issues Research Unit (AWIRU) and Green Cross International (GCI), 787 Pretoria and Geneva.

Prechtl J, Kneip C, Lockhart P, Wenderoth K, Maier U-G. 2004. Intracellular spheroidal bodies of Rhopalodia gibba have nitrogen-fixing apparatus of cyanobacterial origin. Molecular Biology \& Evolution 21 : 1477-1481. Sciences 68 : 310-337.

Reddy, KR, Patrick WH. 1984. Nitrogen transformations and loss in flooded soils and 798 sediments. CRC Critical Reviews in Environmental Control 13 : 273-309. 799

800

Schuyt KD. 2005. Economic consequences of wetland degradation for local 802

803 populations in Africa. Environmental Economics 53 : 117-190.

Stevenson RJ. 1997. Scale-dependent determinants and consequences of benthic algal 805

806 Struyf E, Conley DJ. 2009. Silica: an essential nutrient in wetland biogeochemistry.

$807 \quad$ Frontiers in Ecology 7 : 88-94.

808

809 Suthers IM, Gee JH. 1986. Role of hypoxia in limiting diel spring and summer

810 distribution of juvenile yellow perch (Perca flavescens) in a prairie march. Canadian 811 Journal of Fisheries \& Aquatic Sciences 43 : 1562-1570. 
813 ter braak CJF, Šmilaeur P. 2002. CANOCO reference manual and Canodraw for

814 Windows User's Guide: software for canonical community ordination (version 4.5).

815 Microcomputer Power, Ithica, NY.

816

817 Tibby J, Gell PA, Fluin J, Sluiter IRK. 2007. Diatom-salinity relationships in

818 wetlands: assessing the influence of salinity variability on the development of

819 inference models. Hydrobiologia 591 : 207-218.

820

821

UNEP 2000. Global Environmental Outlook.

822 http://www.unep.org/geo2000/english/0055.htm. Page accessed 1-08-10.

823

824 Van Dam H, Mertens A, Sinkeldam, J. 1994. A coded checklist and ecological

825 indicator values of freshwater diatoms from the Netherlands. Netherlands Journal of

826 Aquatic Ecology 28 : 117-133.

827

828 Weilhoefer CL, Pan Y, Eppard S. 2008. The effects of river floodwaters on floodplain

829 wetland water quality and diatom assemblages. Wetlands 28 : 473-486.

830

831 Wilcox DA, Meeker JE, Hudson PL, Armitage BJ, Black MG, Uzarski DG. 2002.

832 Hydrologic variability and the application of index of biotic integrity metrics to

833 wetlands: a Great Lakes evaluation. Wetlands 22 : 588-615.

834

835 Wolski P, Murray-Hudson M. 2006a. Flooding dynamics in a large low-gradient

836 alluvial fan, the Okavango Delta from analysis and interpretation of 30-year

837 hydrometric record. Hydrology \& Earth System Sciences 10 : 127-137.

838

839 Wolski P, Murray-Hudson M. 2006b. Reconstruction of 1989-2005 inundation history

840 in the Okavango Delta, Bostwana from archival Landsat imagery, Globwetland

841 Symposium. ESA-ESRIN, Frascati, Italy, 19-20 October 2006.

842

843

844

845 
846

847 Acknowledgements

848 We would like to thank the main sponsors of this work, UK Department for

849 Environment, Food and Rural Affairs (DEFRA) The Darwin Initiative: reference 14-

850 029. We would also especially like to thank the technicians and field assistants who

851 worked directly on the collection and analyses of chemistry data, and to the

852 Department of Water Affairs for their help in the field through the provision of boats

853 and drivers when needed. A.W.M. would like to thank Dr Christine Cocquyt

854 (National Botanic Garden of Belgium) for help with diatom identification and Dr

855 Roger Flower and Dr David Adger for providing comments on an earlier draft of the

856 manuscript.

857

858 Author contributions

859 A.W.M. and M.T. conceived the ideas; A.W.M., T.D., P.W., S.W., R.M. collected the 860 data; P.W. undertook analyses of remotely sensed data; W.R.L.M. supervised the 861 analyses of the hydrochemistry data; A.W.M. and T.D. analysed the data; A.W.M. led 862 the writing; ALL contributed to the writing of the manuscript.

863 
864 Table 1: Sites grouped according to their TWINSPAN classification. Most abundant 865 species in each group are given in the bottom panel, while indicator taxa are 866 highlighted in bold. Refer to Appendix S1 for species codes.

867

\begin{tabular}{|c|c|c|c|c|c|}
\hline Group 1 (9) & Group 2 (30) & Group 3 (33) & Group 4 (11) & Group 5 (7) & Group $6(10)$ \\
\hline $\begin{array}{l}\text { UPH1B-3 } \\
\text { UPH3B-3 } \\
\text { UPH4B-3 } \\
\text { UPH5B-3 } \\
\text { UPH6-3 } \\
\text { UPH7B-3 } \\
\text { UPH8A-3 } \\
\text { UPH8B-3 } \\
\text { UPH9C-3 }\end{array}$ & $\begin{array}{l}\text { BOR12-2 } \\
\text { LPH1A-1 } \\
\text { LPH1A-2 } \\
\text { LPH2-1 } \\
\text { LPH2-2 } \\
\text { LPH3A-1 } \\
\text { LPH3A-2 } \\
\text { LPH3B-1 } \\
\text { LPH3B-2 } \\
\text { LPH4A-1 } \\
\text { LPH4A-2 } \\
\text { LPH4B-1 } \\
\text { LPH4C-1 } \\
\text { LPH5A-1 } \\
\text { LPH5B-1 } \\
\text { LPH5C-1 } \\
\text { LPH6-1 } \\
\text { LPH8A-4 } \\
\text { LPH9A-4 } \\
\text { LPH9B-4 } \\
\text { UPH4A-1 } \\
\text { UPH4B-1 } \\
\text { UPH5A-1 } \\
\text { XAK10B-2 } \\
\text { XAK12-3 } \\
\text { XAK19A-4 } \\
\text { XAK3B-2 } \\
\text { XAK4B-3 } \\
\text { XAK5A-2 } \\
\text { XAK5B-2 }\end{array}$ & $\begin{array}{l}\text { LPH1B-1 } \\
\text { LPH1B-2 } \\
\text { LPH1C-1 } \\
\text { LPH1C-2 } \\
\text { LPH4B-2 } \\
\text { LPH5A-2 } \\
\text { LPH5C-2 } \\
\text { NGA1-1 } \\
\text { SAN1-1 } \\
\text { SAN2-1 } \\
\text { SAN3-1 } \\
\text { SAN5-1 } \\
\text { SAN6-1 } \\
\text { THA2-4 } \\
\text { THA3-4 } \\
\text { UPH1B-2 } \\
\text { UPH1B-1 } \\
\text { UPH1C-1 } \\
\text { UPH3A-1 } \\
\text { UPH3B-1 } \\
\text { UPH4A-2 } \\
\text { UPH5A-2 } \\
\text { UPH5B-1 } \\
\text { UPH5B-2 } \\
\text { UPH5C-1 } \\
\text { UPH5C-2 } \\
\text { XAK1-2 } \\
\text { XAK11-2 } \\
\text { XAK2A-2 } \\
\text { XAK2B-2 } \\
\text { XAK6A-2 } \\
\text { XAK6B-2 } \\
\text { XAK8-2 }\end{array}$ & $\begin{array}{l}\text { BOR13B-3 } \\
\text { BOR17A-4 } \\
\text { BOR18-4 } \\
\text { BOR19-4 } \\
\text { LPH4C-2 } \\
\text { SAN7-3 } \\
\text { XAK13A-3 } \\
\text { XAK14-3 } \\
\text { XAK15-3 } \\
\text { XAK16A-3 } \\
\text { XAK16B-3 }\end{array}$ & $\begin{array}{l}\text { BOR16-3 } \\
\text { BOR8A-3 } \\
\text { NGA2-1 } \\
\text { SAN4-1 } \\
\text { XAK7-2 } \\
\text { XAK7-3 } \\
\text { XAK9-2 }\end{array}$ & $\begin{array}{l}\text { BOR10A-3 } \\
\text { BOR10B-3 } \\
\text { BOR14A-3 } \\
\text { BOR14B-3 } \\
\text { BOR15-3 } \\
\text { BOR2B-3 } \\
\text { BOR9A-3 } \\
\text { XAK13B-3 } \\
\text { XAK13C-3 } \\
\text { XAK1A-3 }\end{array}$ \\
\hline $\begin{array}{l}\text { EunPectM } \\
\text { EunPectU } \\
\text { BracBreb } \\
\text { FrusCras }\end{array}$ & $\begin{array}{l}\text { GompParv } \\
\text { GompGrac } \\
\text { EunPectM } \\
\text { EunRhomb } \\
\text { EunNaege } \\
\text { AchMinut }\end{array}$ & $\begin{array}{l}\text { GompParv } \\
\text { GompGrac } \\
\text { EunPectM } \\
\text { AchMinut } \\
\text { EunNaege }\end{array}$ & $\begin{array}{l}\text { GompParv } \\
\text { EunPectM } \\
\text { EunPectU } \\
\text { EunNaege }\end{array}$ & $\begin{array}{l}\text { GompParv } \\
\text { GompGrac } \\
\text { EunPectM } \\
\text { NitzBaca } \\
\text { CratBude } \\
\text { AulAmbig }\end{array}$ & $\begin{array}{l}\text { PinnGibb } \\
\text { NitzBaca } \\
\text { GompParv } \\
\text { CratBude } \\
\text { AulGranu }\end{array}$ \\
\hline
\end{tabular}


870

871 Table 2: Principal components analysis (PCA) of diatom dataset.

\begin{tabular}{lccccc}
\hline & PCA Axes & & & Total Variance \\
\hline & 1 & 2 & 3 & 4 & 1 \\
Eigenvalues & 0.152 & 0.121 & 0.095 & 0.056 & \\
Cum. \% var. spp data & 15.2 & 27.3 & 36.8 & 42.4 & \\
Broken stick variances & 0.048 & 0.039 & 0.034 & 0.031 &
\end{tabular}

872

873

874

875 
876 Table 3: Redundancy analysis (RDA) of species data with four hydrological variables 877 as explanatory variables, and latitude - longitude coordinates partialled out as co878 variables

879

\begin{tabular}{llllll}
\hline & RDA Axes & & & \\
& 1 & 2 & 3 & 4 & Total Variance \\
\hline & & & & & \\
Eigenvalues & 0.052 & 0.023 & 0.016 & 0.009 & 1 \\
Cum. \% var spp. data & 5.7 & 8.3 & 10.1 & 11 & \\
& & & & & 0.903 \\
Sum of all eigenvalues & & & & & 0.1 \\
Sum of all canonical eigenvalues; $\mathrm{p}=0.002$ & & & & & \\
\hline
\end{tabular}

880

881

882

883 
Table 4: \% contributions to diatom variation of each of the four hydrological variables as determined using RDA of 100 sample points. Unique contributions have also been 889 calculated, with the remaining 3 variables as co-variables. Contributions to diatom variation with season and site proximity as co-variables are also shown. All values are significant to at least $\mathrm{p}=0.008$, except $*(\mathrm{p}>0.05)$.

\begin{tabular}{lcccc} 
& $\begin{array}{c}\text { Single } \\
\text { variable }\end{array}$ & $\begin{array}{c}\text { Other hydrological } \\
\text { variables partialled out }\end{array}$ & $\begin{array}{c}\text { Season } \\
\text { partialled out }\end{array}$ & $\begin{array}{c}\text { Proximity } \\
\text { partialled out }\end{array}$ \\
\hline Depth & 3.7 & 1.8 & 3.3 & $1^{*}$ \\
Velocity & 2.2 & 2.2 & 2.1 & 1.8 \\
Flood frequency & 4.1 & 2.3 & 4.2 & 2.5 \\
Hydroperiod class & 5.5 & 4 & 4.6 & 2.5 \\
\hline
\end{tabular}


Table 5: Summary statistical analyses for hydrological and hydrochemical data measured for the reduced dataset of 53 sample points. Summary statistical data for the 4 hydrological variables are also given for the full dataset of 100 sample points for comparison.

923

\begin{tabular}{|c|c|c|c|c|c|}
\hline Explanatory variable & $\mathrm{N}$ & Minimum & Maximum & Mean & S.D. \\
\hline Depth (m) & 100 & 0.0 & 4.4 & 1.5 & 1.1 \\
\hline Velocity $(\mathrm{m} / \mathrm{s})$ & 100 & 0.0 & 1.6 & 0.1 & 0.3 \\
\hline Flood frequency & 100 & 1.0 & 15.0 & 13.0 & 3.9 \\
\hline Hydroperiod class & 100 & 1.0 & 7.0 & 4.9 & 1.9 \\
\hline Depth (m) & 53 & 0.0 & 4.3 & 1.6 & 1.2 \\
\hline Velocity $\left(\mathrm{m} \mathrm{s}^{-1}\right)$ & 53 & 0.0 & 1.6 & 0.2 & 0.4 \\
\hline Flood frequency & 53 & 1.0 & 15.0 & 13.9 & 2.9 \\
\hline Hydroperiod class & 53 & 1.0 & 7.0 & 5.0 & 1.7 \\
\hline $\mathrm{pH}$ (pH units) & 53 & 4.7 & 9.1 & 6.7 & 0.7 \\
\hline Conductivity $\left(\mu \mathrm{S} \mathrm{cm}^{-1}\right)$ & 53 & 20.7 & 236.0 & 64.7 & 35.3 \\
\hline $\mathrm{DOC}\left(\mathrm{mg} \mathrm{L}^{-1}\right)$ & 53 & 3.3 & 34.4 & 8.8 & 6.2 \\
\hline $\mathrm{SiO}_{2}\left(\mathrm{mg} \mathrm{L}^{-1}\right)$ & 53 & 4.1 & 32.3 & 15.7 & 8.6 \\
\hline $\mathrm{TP}\left(\mathrm{mg} \mathrm{L}^{-1}\right)$ & 53 & 0.0 & 0.1 & 0.0 & 0.0 \\
\hline $\mathrm{TN}\left(\mathrm{mg} \mathrm{L}^{-1}\right)$ & 53 & 0.1 & 1.9 & 0.6 & 0.4 \\
\hline $\mathrm{HCO}_{3}\left(\mathrm{mg} \mathrm{L}^{-1}\right)$ & 53 & 3.5 & 100.0 & 49.2 & 21.6 \\
\hline $\mathrm{Cl}\left(\mathrm{ug} \mathrm{L}^{-1}\right)$ & 53 & 0.2 & 14.5 & 1.2 & 2.4 \\
\hline $\mathrm{SO}_{4}\left(\mathrm{mg} \mathrm{L}^{-1}\right)$ & 53 & 0.0 & 12.6 & 0.7 & 1.8 \\
\hline $\mathrm{K}\left(\mathrm{mg} \mathrm{L}^{-1}\right)$ & 53 & 0.5 & 17.1 & 2.6 & 2.4 \\
\hline $\mathrm{Na}\left(\mathrm{mg} \mathrm{L}^{-1}\right)$ & 53 & 0.5 & 3.0 & 1.3 & 0.6 \\
\hline $\operatorname{Mg}\left(\mathrm{mg} \mathrm{L}^{-1}\right)$ & 53 & 0.1 & 2.6 & 0.7 & 0.5 \\
\hline
\end{tabular}


935

936

937

938

939

940

\begin{tabular}{llllll}
\hline RDA Axes & & & & \\
& 1 & 2 & 3 & 4 & Total Variance \\
\hline
\end{tabular}

Eigenvalue

Cum. \% var spp. data $\begin{array}{lllll}0.133 & 0.079 & 0.036 & 0.021 & 1\end{array}$

$\begin{array}{llll}13.3 & 21.3 & 24.9 & 27.0\end{array}$

Sum of all canonical EVs; $p=0.002$ 0.286 941 942 943 944 945 946 947 948 949 950 951 952 953 954 955 956 957 958 959 960 961 962 963 964 965 966 


\section{Figure Legends}

969

970 Figure 1: Map of the Okavango Delta and its catchment basin straddling three

971 countries Angola, Namibia and Botswana. Principal regions studied are indicated:

972 UPH (upper Panhandle); LPH (lower Panhandle); XAK (Xakanaxa region) BOR (Jao

973 /Boro river system), SAN (Santantadibe), THA (Thamalakane), NGA (Lake Ngami).

974

975 Figure 2: Biplots of linear discriminant analysis of diatom communities classified

976 according to their TWINSPAN grouping; (a) hydrological variables and (b) diatom

977 guilds as predictor variables. Both biplots show Axis 1 plotted against Axis 2.

978

979 Figure 3: Principal components analysis (PCA) biplot (axes 1 and 2) of diatom

980 species. Sample points $(n=100)$ have been coded according to their TWINSPAN

981 groupings.

982

983 Figure 4: Redundancy (RDA) triplot (axes 1 and 2) with sample points ( $=53$ ) coded

984 according to their TWINSPAN grouping, and forward selected explanatory variables

985 shown.

986

987 Figure 5: Species response curves (SRC) for major taxa fitted with a generalized

988 additive model (GAM). SRCs are grouped according to (a) guild 1 (low); (b, c) guild

9892 (high); (d) guild 3 (motile).

990

991 


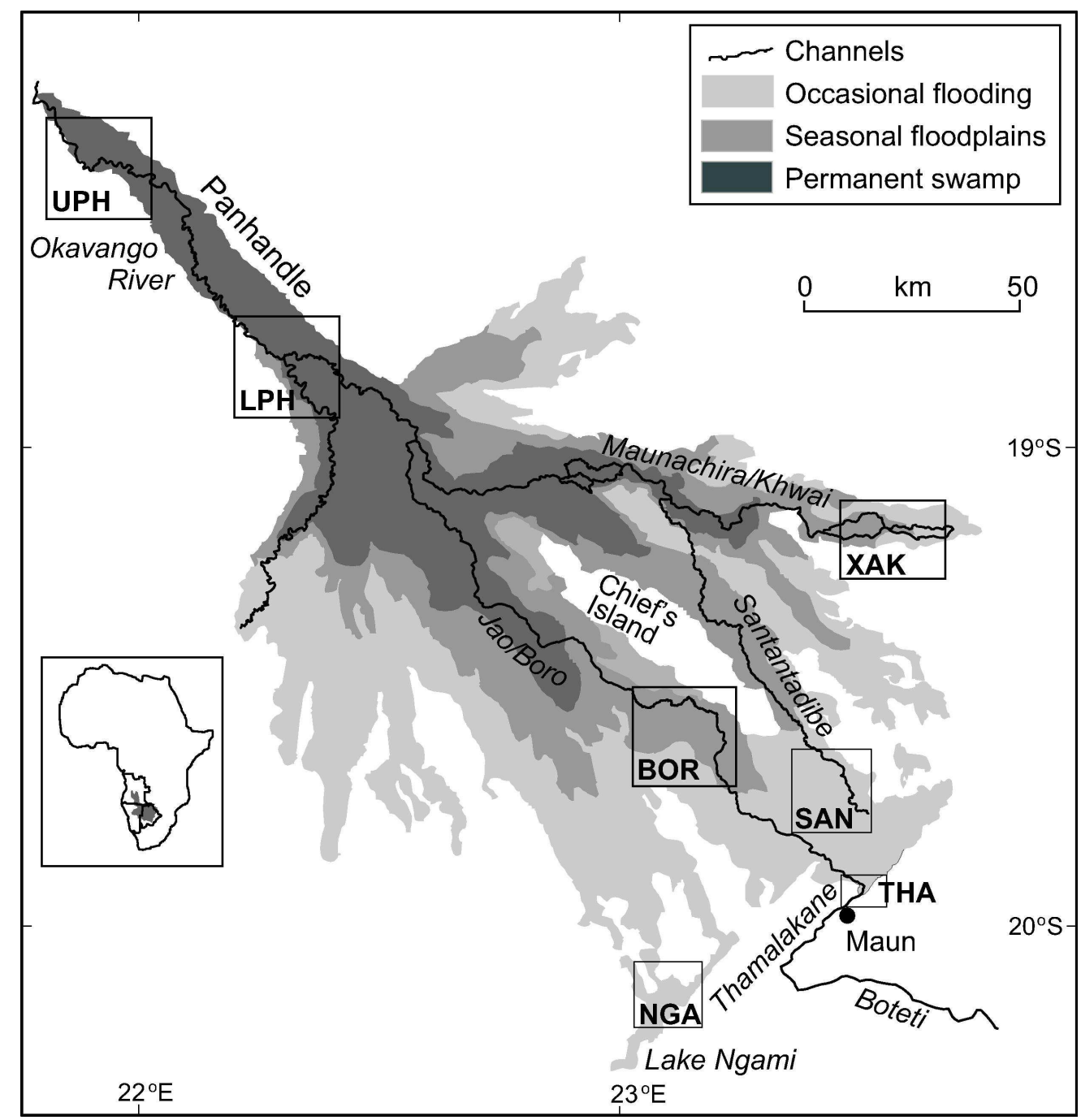

Figure 1: Map of the Okavango Delta and its catchment basin straddling three countries Angola, Namibia and Botswana. Principal regions studied are indicated: UPH (upper Panhandle); LPH (lower Panhandle); XAK (Xakanaxa region) BOR (Jao /Boro river system), SAN (Santantadibe), THA (Thamalakane), NGA (Lake Ngami). $105 \times 110 \mathrm{~mm}(600 \times 600 \mathrm{DPI})$ 

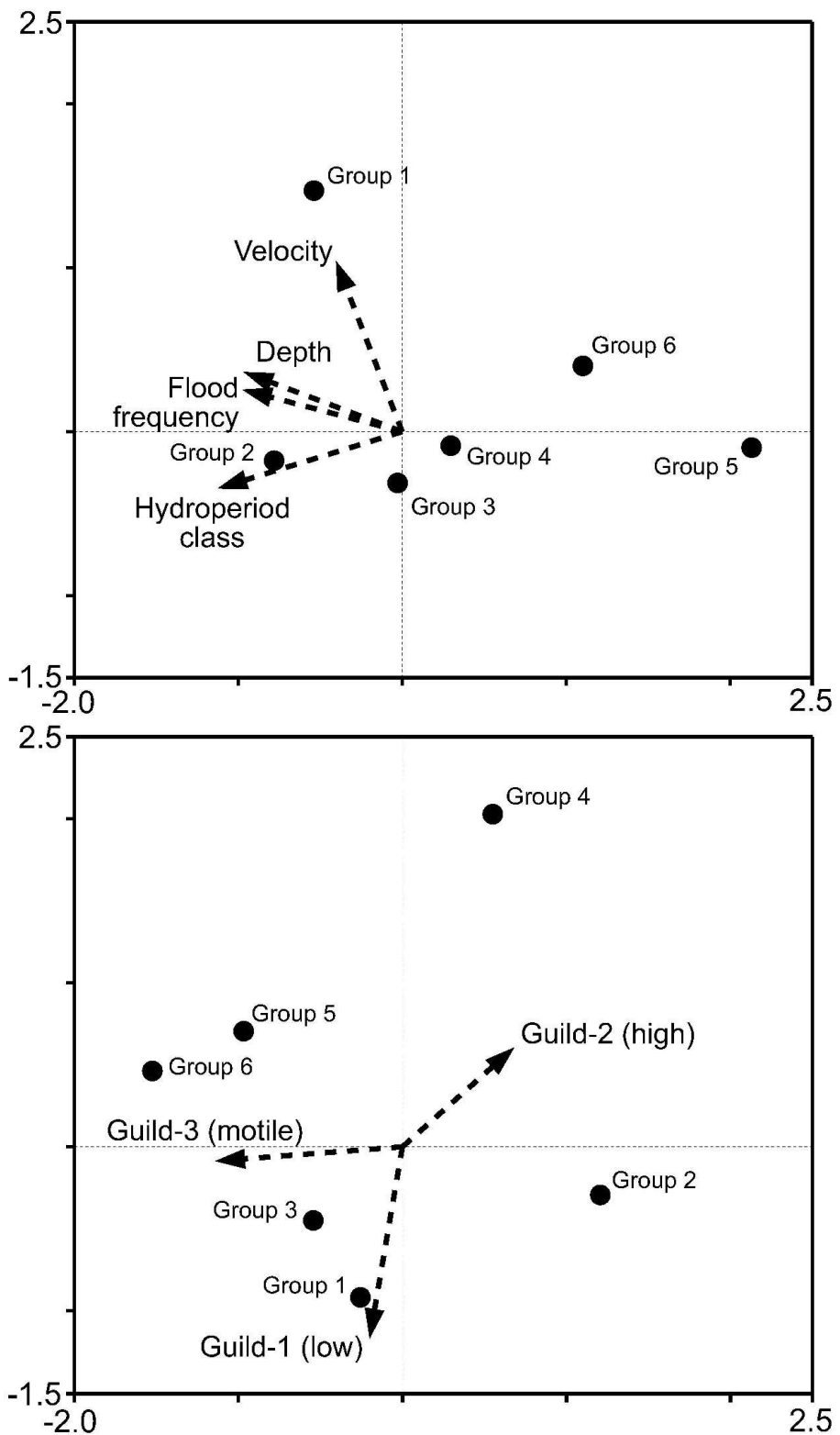

Figure 2: Biplots of linear discriminant analysis of diatom communities classified according to their TWINSPAN grouping; (a) hydrological variables and (b) diatom guilds as predictor variables. Both biplots show Axis 1 plotted against Axis 2 $106 \times 182 \mathrm{~mm}(600 \times 600 \mathrm{DPI})$ 


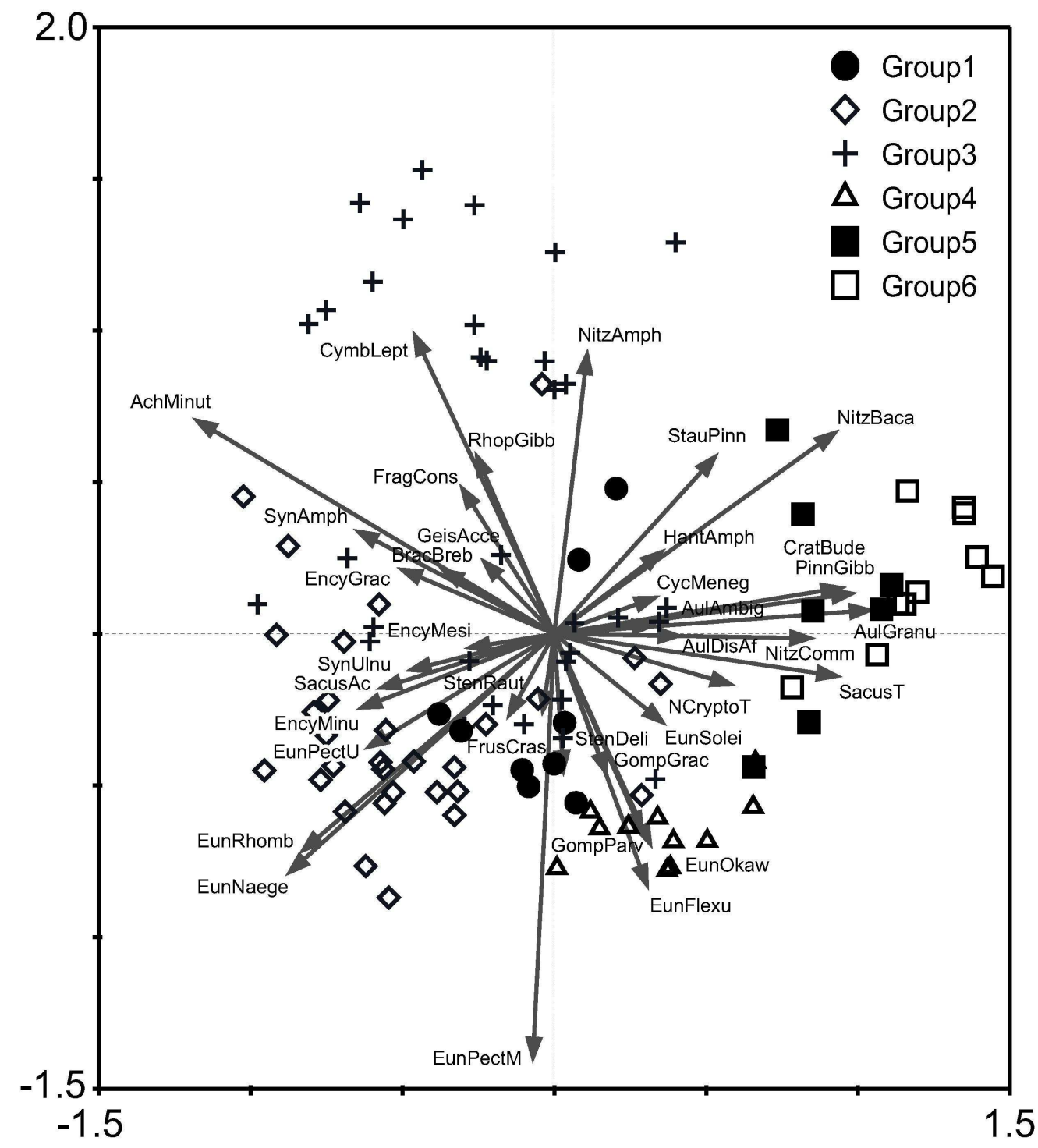

Figure 3: Principal components analysis (PCA) biplot (axes 1 and 2) of diatom species. Sample points $(n=100)$ have been coded according to their TWINSPAN groupings. $104 \times 118 \mathrm{~mm}(600 \times 600 \mathrm{DPI})$ 


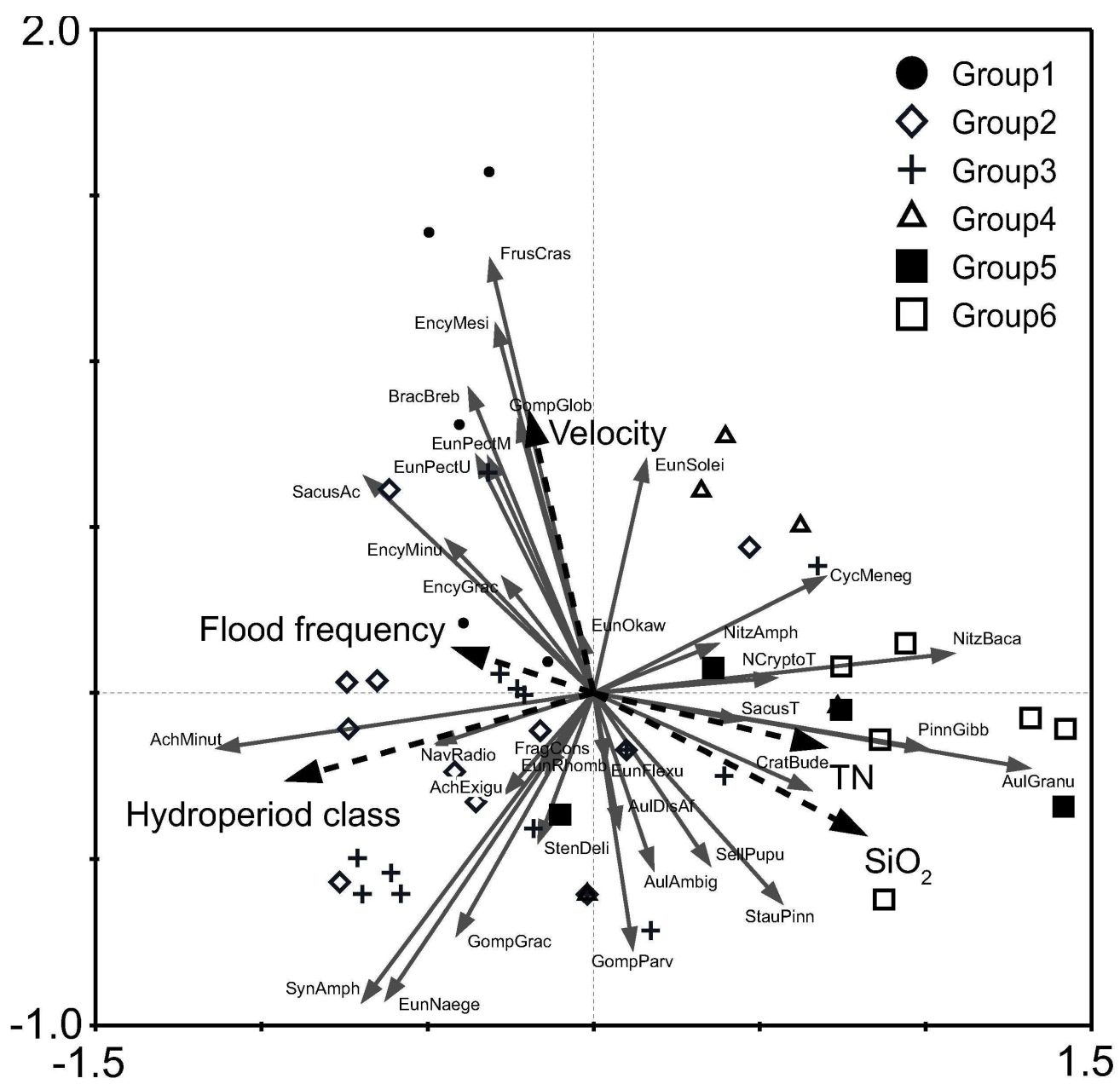

Figure 4: Redundancy (RDA) triplot (axes 1 and 2 ) with sample points ( $n=53$ ) coded according to their TWINSPAN grouping, and forward selected explanatory variables shown. $106 \times 102 \mathrm{~mm}(600 \times 600 \mathrm{DPI})$ 

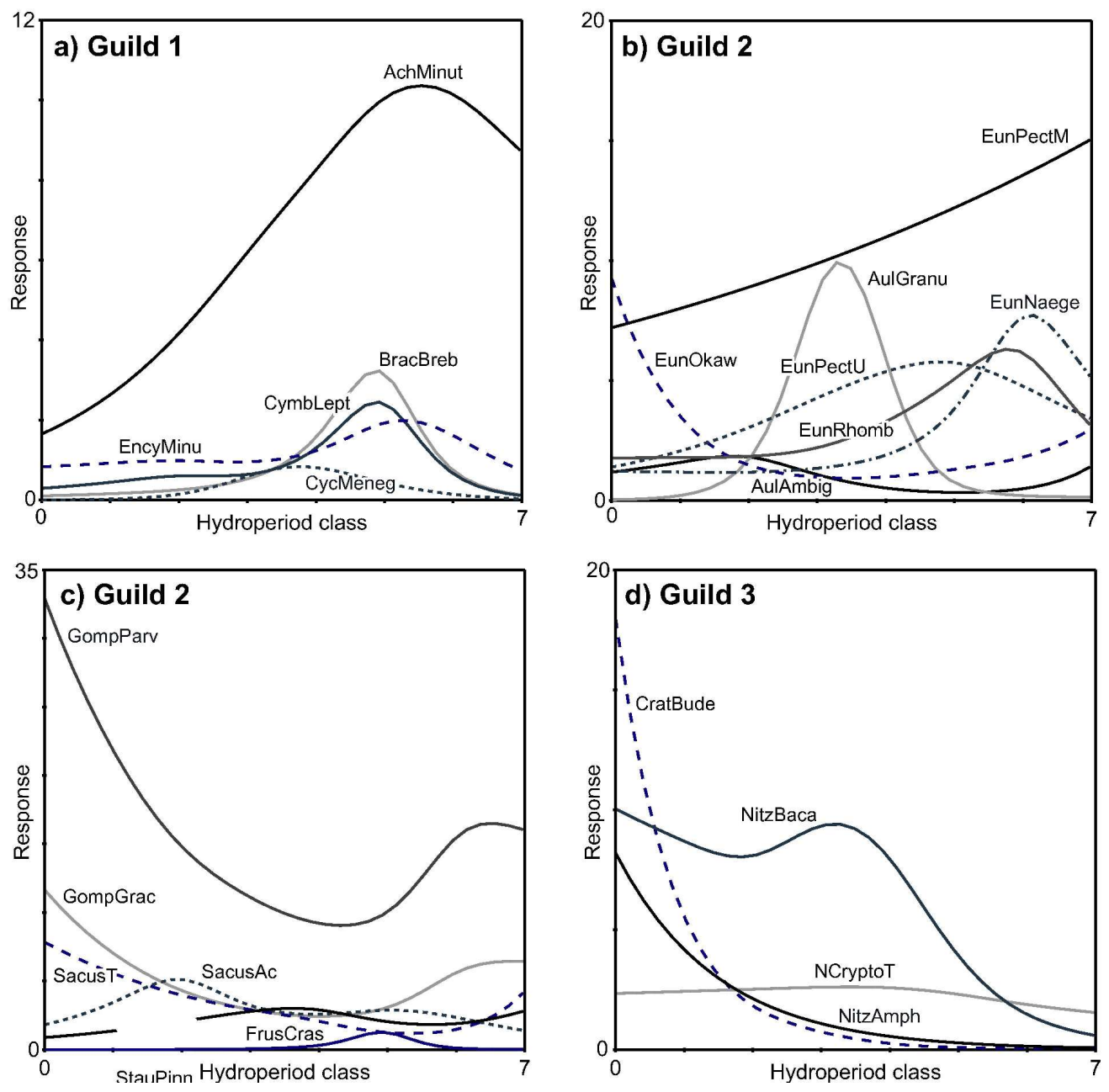

Figure 5: Species response curves (SRC) for major taxa fitted with a generalized additive model (GAM). SRCs are grouped according to (a) guild 1 (low); (b, c) guild 2 (high); (d) guild 3 (motile). $161 \times 158 \mathrm{~mm}(600 \times 600 \mathrm{DPI})$ 